\title{
HEALTH AGENT AWARD SEBAGAI CORPORATE SOCIAL RESPONSIBILITY PT NUTRIFOOD INDONESIA
}

\author{
Amelinda Vindrayani Fuad ${ }^{1}$, Susanne Dida ${ }^{2}$, dan Kokom Komariah ${ }^{3}$ \\ Universitas Padjadjaran
}

\begin{abstract}
ABSTRAK
Penelitian ini bertujuan untuk memaparkan tahap perencanaan, pelaksanaan, pengecekan, dan evaluasi program Health Agent Award 2015 sebagai salah satu program corporate social responsibility PT Nutrifood Indonesia. Metode yang digunakan pada penelitian ini adalah deskrptif.Teknik pengumpulan data yang digunakan adalah wawancara mendalam, observasi, dan studi kepustakaan. Teknik penentuan key informant dengan cara purposive sampling. Teknik validitas data menggunakan triangulasi sumber data. Hasil penelitian ini menunjukkan bahwa pada tahap perencanaan, program Health Agent Award 2015 diselaraskan dengan visi, misi, tujuan, dan target sasaran oleh tim Public Relations. Tahap pelaksanaan dimulai dengan seleksi proposal tim mahasiswa, briefing dan edukasi kepada para Health Agent, pengimplementasian rancangan proyek kesehatan di sekolah dasar oleh tim Health Agent, hingga awarding session di ballroom Hotel Century Park Jakarta. Tahap pengecekan dilakukan satu kali dan dalam bentuk penjurian saat kick-off program di sekolah dasar.Tahap evaluasi dilakukan dalam bentuk laporan untuk membahas kekurangan dan kelebihan program. Simpulan dari program Health Agent Award 2015 sebagai corporate social responsibility adalah, program telah dijalankan dengan baik oleh PT Nutrifood Indonesia. Saran diberikan pada tahap perencanaan CSR sebaiknya melibatkan top management. Pada tahap pelaksaan CSR, tim Public Relations lebih berperan aktif dengan menjadi mentor di lapangan bagi para tim Health Agent. Tahap pengecekan sebaiknya tidak hanya sekali, melainkan paling tidak dua minggu sekali untuk mengetahui perubahan yang terjadi di lapangan. Tahap evaluasi sebaiknya juga mempertimbangkan cara untuk sustainability program di sekolah dasar.
\end{abstract}

Kata-kata Kunci: Implementasi, public relations, corporate social responsibility, health agent award, pt nutrifood indonesia

\section{THE IMPLEMENTATION OF HEALTH AGENT AWARD 2015 PROGRAM AS PT NUTRIFOOD INDONESIA'S CORPORATE SOCIAL RESPONSIBILITY} \begin{abstract}
This study aims to explain about the planning, the implementation, the examination, and the evaluation of the Health Agent Award 2015 as one of corporate social responsibility programs of PT Nutrifood Indonesia.This study applied descriptive as the method. The technique of data collection was conducted by more in-depth interviews, observation, and literature review. To determine the key informant was conducted by purposive sampling technique.. The technique of validity data used triangulation of data sources. The result of this study showed that at the planning stage, the Health Agent Award 2015 program is aligned with the various aspects, such as vision, mission, goals, and target with the Public Relations team which there is no involvement of top management. The implementation of the Health Agent Award 2015 program was begun through selection of proposal student team, briefing and gave an education to Health Agent team, implemented the health project in the elementary school, until awarding session in the ballroom Century Park Hotel Jakarta. The examination stage was only conducted once in formed of judging while kick-off program in the elementary. The evaluation stage is done either by the Health Agent and Public Relations team in the form of a report to discuss the advantages and disadvantages of the program.In conclusion, the of Health Agent Award 2015 as corporate social responsibility was run well by PT Nutrifood Indonesia. The advices that can be given is CSR planning should involve top management too. When implement CSR, particularly when Health Agent implemented health project, Public Relations team should has more an active role through become a mentor for the Health Agent team. The examination will be better was done more than one time, instead two times a week to investigate and to see the changes that was occuring in the field. Moreover, the evaluation should consider the way for sustainability program in elementary school.
\end{abstract}

Keywords: Implementation, public relations, corporate social responsibility, health agent award, pt nutrifood indonesia

Korespondensi: Amelinda Vindrayani Fuad, S.I.Kom. Program Studi Hubungan Masyarakat, Fakultas Ilmu Komunikasi, Universitas Padjadjaran, Jl. Raya Bandung-Sumedang Km 21, Jatinangor 45363. Email: avindrayani19@gmail.com 


\section{PENDAHULUAN}

Corporate Social Responsibility (CSR) merupakan suatu bentuk tindakan nyata perusahaan atau kepekaan dan kepedulian untuk berkontribusi terhadap lingkungan sosial dalam memberikan manfaat, menyelesaikan masalah, serta meningkatkan kualitas hidup masyarakat. CSR dapat dikatakan sebagai salah satu instrumen inovatif yang dapat membantu perusahaan untuk peka dan adaptif terhadap lingkungan dan kehidupan masyarakat.

Di Indonesia, pemerintah membuat Undang-Undang Nomor 40 Tahun 2007 yang berisikan peraturan mengenai tanggung jawab sosial dan lingkungan perusahaan yang bertujuan untuk mewujudkan pembangunan ekonomi yang berkelanjutan guna meningkatkan kualitas kehidupan dan lingkungan yang bermanfaat bagi perusahaan itu sendiri, komunitas setempat, dan masyarakat umumnya. CSR juga dimaksudkan untuk mendukung terjadinya hubungan perusahaan yang seimbang, serasi, dan sesuai dengan lingkungan, nilai dan norma, serta budaya masyarakat setempat.

Kini CSR juga dipandang sebagai bagian dari strategi bisnis korporasi yang berkaitan dengan keberlangsungan usaha jangka panjang. CSR bukan lagi hanya sebatas kegiatan amal, melainkan mengharuskan perusahaan dalam mengambil keputusan memperhitungkan dengan sungguh-sungguh akibat yang akan terjadi pada seluruh pemangku kepentingan (stakeholders) dan lingkungan. Maka, CSR baiknya selaras dengan visi dan misi perusahaan.

PT Nutrifood Indonesia merupakan perusahaan swasta nasional yang bergerak di bidang industri makanan dan minuman kesehatan. Sebagai suatu perseroan terbatas yang memikirkan keberlangsungannya saat ini dan di masa mendatang, PT Nutrifood Indonesia melakukan kegiatan CSR yang sejalan dengan pilar perusahaan, yaitu menginspirasi dan membantu masyarakat meningkatkan kualitas hidup melalui pola hidup sehat dan nutrisi seimbang. Salah satu kegiatan CSR PT Nutrifood Indonesia adalah program Health Agent Award 2015.

\section{Program Health Agent Award 2015}

merupakan gerakan edukasi mengenai pentingnya gaya hidup sehat dan keamanan pangan yang dilakukan dengan cara yang menyenangkan. Program ini ditujukan kepada komunitas sekolah dasar, yakni murid, guru, pedagang kantin, hingga orang tua, karena kebiasaan baik untuk anak-anak sudah seharusnya ditanamkan sejak dini, termasuk perilaku hidup bersih dan sehat, serta mengkonsumsi makanan bernutrisi dan bergizi seimbang. Program ini merupakan salah satu bentuk kontribusi nyata PT Nutrifood Indonesia dalam membantu menyelesaikan permasalahan kesehatan terkait angka penderita Penyakit Tidak Menular (PTM) yang semakin meningkat dan menyasar kepada tingkat usia anak-anak.

"Kebiasaan baik untuk anak-anak harus ditanamkan sedini mungkin. Kebiasaan baik itu antara lain perilaku hidup bersih serta mengkonsumsi makanan bernutrisi dan bergizi seimbang. Berdasarkan hasil Riset Kesehatan Dasar tahun 2013, angka penderita Penyakit Tidak Menular (PTM), seperti jantung, stroke, diabetes, kanker, dan lainnya, kian meningkat dan semakin menyasar kepada tingkat usia yang lebih muda." Arninta P. (2016, 3 Maret)

Semua sekolah dasar yang dijadikan target program Health Agent Award 2015 berlokasi di Jakarta karena PT Nutrifood Indonesia ingin berkontribusi bagi masyarakat di sekitar perusahaannya beroperasi, mengingat kantor pusat PT Nutrifood Indonesia berlokasi di Jakarta, dan juga jumlah sekolah dasar di Jakarta yang banyak, dimana mayoritas sekolah dasar tersebut membutuhkan bimbingan dan edukasi tentang kesehatan.

"Nutrifood ingin berkontribusi dengan menginspirasi gaya hidup sehat dan asupan nutrisi yang seimbang kepada masyarakat, dimulai dari masyarakat yang terdekat dengantempatNutrifood beroperasi. Karena kantor pusat Nutrifood di Jakarta, serta berdasarkan data yang Nutrifood miliki, sekolah dasar di Jakarta saja jumlahnya sekitar tiga ribu sekolah, dan masih banyak yang belum memenuhi standard kesehatan, makanya kita menargetkan sekolah dasar yang di Jakarta." (Wawancara Arninta P. 3 Maret 2016) 
Program Health Agent Award 2015 memiliki keunikan dan kelebihan dalam melibatkan beberapa stakeholder untuk melakukan gerakan edukasi pola hidup bersih dan jajanan sehat kepada komunitas sekolah dasar. Pertama, PT Nutrifood Indonesia mengkomunikasikan dengan Kementerian Kesehatan RI dan juga Badan Pengawas Obat dan Makanan (BPOM) untuk mengajak berkolaborasi karena program Health Agent Award 2015 selaras dengan kampanye Kementerian Kesehatan Republik Indonesia, yakni Perilaku Hidup Bersih dan Sehat, serta kampanye Keamanan Pangan Kantin Sekolah yang dicanangkan oleh Badan Pengawas Obat dan Makanan (BPOM).

Selanjutnya, PT Nutrifood Indonesia mengkomunikasikan kepada para mahasiswa untuk mengajak mereka, selaku agen perubahan, bersama-sama berkontribusi memberikan pemahaman mengenai pentingnya gaya hidup sehat sejak dini dan keamanan pangan kepada komunitas sekolah dasar melalui kreativitas proyek inspirasi gaya hidup sehat. Pemilihan mahasiswa sebagai agen (pihak ketiga) melalui kompetisi merupakan langkah cerdas yang diambil oleh PT Nutrifood Indonesia, karena mahasiswa juga digunakan sebagai sarana untuk create word of mouth.

Kompetisi Health Agent Award 2015 terbuka untuk seluruh mahasiswa S1 aktif se-Jabodetabek dan Bandung, artinya tidak terkhusus bagi mahasiswa yang berkuliah di jurusan atau universitas tertentu. Peserta kompetisi ini berupa tim yang masing-masing terdiri dari tiga orang.

Pada penyelenggaraan program Health Agent Award 2015, terdapat 122 tim mahasiswa dari berbagai universitas yang mengirimkan proposal rancangan proyek kesehatan mereka, namun hanya 15 tim mahasiswa yang berhasil terpilih menjadi Health Agent. Jumlah tersebut disesuaikan dengan jumlah sekolah dasar yang menjadi target Health Agent Award 2015.

"Health Agent Award 2015 terbuka bagi seluruh mahasiswa aktif S1 se-Jabodetabek dan Bandung. Untuk menjadi Health Agent, tentunya mereka harus lolos setiap tahapan seleksi, mulai dari menginput proposal proyek kesehatan di lingkungan sekolah dasar, hingga mempresentasikan proyek tersebut di kantor pusat Nutrifood yang berlokasi di Pulogadung Jakarta, karena kami hanya mencari 15 tim Health Agent. Jumlah ini sesuai dengan jumlah sekolah dasar yang menjadi target Nutrifood pada Health Agent Award 2015." Arninta P. (2016, 3 Maret)

Sebelum turun ke lapangan, setiap Health Agent diperiksa kesehatannya, serta di briefing dan diberikan edukasi. Setiap tim Health Agent pun difasilitasi oleh PT Nutrifood Indonesia berupa uang tunai masing-masing sebesar Rp 1.000.000,- untuk mengimplementasikan proyek mereka selama satu setengah bulan dan juga uang trasnportasi sebesar Rp 500.000,-.

Ketika pelaksanaan implementasi proyek dari kesehatan tim Health Agent di sekolah dasar, pihak PT Nutrifood Indonesia kurang berpatisipasi aktif. Pihak PT Nutrifood Indonesia hanya datang pada satu hari, saat kick-off program, untuk melakukan penjurian. Fadhil Bayu Pratama, sebagai ketua tim The Hobbit, menyatakan bahwa saat timnya mengimplementasikan proyek kesehatan di sekolah dasar, tidak ada mentor yang mendampingi timnya, serta tidak ada pengontrolan rutin dari PT Nutrifood Indonesia.

"Pas kita lagi implementasiin proyek kesehatan di sekolah dasar, kita gak dikasih mentor dari Nutrifood. Padahal kita sih pengennya ada mentor gitu untuk mengontrol proyek kita dan bisa jadi tempat sharing. Trus gak ada pengontrolan yang rutin dari Nutrifood, mereka cuma datang sekali, pas kick-off program, untuk menilai proyek kita." Pratama, F. B. (2016, 7 Maret).

Muhammad Kholik, ketua tim Komandan Sehat, juga menyatakan hal serupa, "Selama kita mengimplementasikan proyek kesehatan di sekolah dasar kemarin, kita gak dapet briefing dan pengontrolan rutin dari Nutrifood." Pada kompetisi Health Agent Award 2015 juga terdapat penjurian yang dilakukan oleh PT Nutrifood Indonesia. Penjurian sebenarnya sudah dimulai dari tahap pertama, namun point terbesar terdapat pada saat tim 
mengimplementasikan proyek inspirasi gaya hidup sehat selama satu setengah bulan di sekolah dasar yang menjadi target. Penjurian ini dilakukan untuk menentukan lima besar juara Health Agent Award 2015, sekaligus merupakan bentuk pengecekan PT Nutrifood Indonesia terhadap implementasi proyek kesehatan para tim Health Agent di setiap Sekolah Dasar.

Program Health Agent Award 2015 diakhiri dengan awarding session di Hotel Century Park Jakarta, yang terdiri dari kegiatan pemberian hadiah kepada para pemenang, press conference, dan juga exhibition yang diisi dengan menampilkan hasil karya dari proyekproyek inspirasi gaya hidup sehat Health Agent Award 2015. PT Nutrifood Indonesia tidak hanya memberikan apresiasi kepada tim mahasiswa yang sudah menjadi Health Agent, tetapi juga kepada pihak Sekolah Dasar.

Berdasarkan uraian konteks penelitian, maka fokus kajian dari penelitian ini adalah "Bagaimana Implementasi Program Health Agent Award 2015 Sebagai Bentuk Corporate Social Responsibility oleh PT Nutrifood Indonesia". Penelitian ini merupakan studi deskriptif mengenai kerangka implementasi dalam program Health Agent Award 2015 sebagai bentuk Corporate Social Responsibility PT Nutrifood Indonesia.

Pertanyaan penelitian yang terlahir dari fokus penelitian adalah sebagai berikut: (1) Bagaimana perencanaan (plan) program Health Agent Award 2015 sebagai Corporate Social Responsibility oleh PT Nutrifood Indonesia; (2) Bagaimana pelaksanaan (do) program Health Agent Award 2015 sebagai Corporate Social Responsibility oleh PT Nutrifood Indonesia?; (3) Bagaimana pengecekan (check) program Health Agent Award 2015 sebagai Corporate Social Responsibility oleh PT Nutrifood Indonesia?; dan (4) Bagaimana evaluasi (evaluate) program Health Agent Award 2015 sebagai Corporate Social Responsibility oleh PT Nutrifood Indonesia.

\section{METODE PENELITIAN}

Penelitian ini menggunakan metode penelitian deskriptif, untuk menggambarkan atau menganalisis implementasi program Health Agent Award 2015 sebagai CSR PT Nutrifood Indonesia, namun hasil penelitian tidak dapat digunakan untuk membuat kesimpulan yang lebih luas (Sugiyono, 2010: 29). Penelitian ini berusaha untuk eksplorasi dan klarifikasi mengenai suatu fenomena, mendeskripsikan sejumlah variabel yang berkenaan dengan masalah dan unit yang diteliti (Faisal, 2007: 20).

Dalam hal ini peneliti (1) Mengumpulkan informasi aktual secara rinci yang berkenaan dengan program Health Agent Award serta melukiskannya (Rakhmat, 2009: 25). Peneliti mengumpulkan informasi dari beberapa key informant dengan menggunakan pedoman wawancara yang sudah dipersiapkan secara rinci untuk mendapatkan informasi yang aktual dan rinci. (2) Mengidentifikasi masalah atau memeriksa kondisi dan praktek-praktek yang berlaku(Rakhmat, 2009:25). Penelitimemeriksa data yang diperoleh dari wawancara dan observasi, serta mengidentifikasi permasalahan apa yang terjadi, memeriksa kondisi, dan mengetahui bagaimana implementasi program Health Agent Award 2015 dilakukan. (3) Membuat perbandingan atau evaluasi (Rakhmat, 2009: 25). Selanjutnya Peneliti membuat perbandingan dan menganalisis data yang diperoleh berdasarkan tinjauan pustaka yang ada. (4) Menentukan apa yang dilakukan orang lain dalam menghadapi masalah yang sama dan belajar dari pengalaman mereka untuk menetapkan rencana dan keputusan pada waktu yang akan datang (Rakhmat, 2009: 25).

Hasil dari penelitian ini menggambarkan bagaimana implementasi program Health Agent Award 2015, penelitian dilakukan secara deduktif. Kasus dalam penelitian ini tidak memiliki keunikan khusus. Namun hasil atau deskripsi yang ditulis diharapkan akan memberikan pengalaman yang berbeda.

\section{HASIL DAN PEMBAHASAN}

Hohnen (2007) menyatakan bahwa sebuah rancangan kerangka implementasi CSR yang baik berintegrasi dalam pengambilan keputusan di bidang ekonomi, sosial, dan lingkungan sebuah perusahaan. CSR juga sekaligus menjadi 
salah satu bentuk tanggung jawab organisasi (Rakhmawati \& Sani, 2016). Kegiatan CSR juga dapat berbentuk gerakan (Yanto, Rodiah, \& Lusiana, 2016).

Hohnen (2007) membuat kerangka kerja untuk membantu perusahaan mengimplementasikan CSR. Kerangka ini terdiri dari perencanaan (plan), pelaksanaan (do), pengecekan (check), evaluasi (evaluate), dan pengecekan kembali (cross-check). Kerangka tersebut juga dimaksudkan menjadi fleksibel dan mendorong perusahaan untuk mengadopsinya dengan menyesuaikan organisasi mereka.

Menurut Hohnen (2007), mendefinisikan petunjuk, instrumen, dan pendekatan CSR merupakan hal yang penting dalam fase perencanaan. Fase perencanaan terdiri dari dua tahap, yaitu tahap membuat penilaian CSR (conduct a CSR assessment) dan tahap mengembangkan strategi CSR (develop a CSR strategy).

Hohnen (2007: 22) menyatakan bahwa membuat penilaian CSR bertujuan untuk mengumpulkan dan memeriksa informasi yang relevan mengenai core perusahaan, seperti produk, pelayanan, pengambilan keputusan, dan aktivitas yang menjiwai berbagai bentuk aktivitas yang menjadi kebijakan organisasi. Praktik CSR harus didasarkan pada landasan yang kuat yang dijadikan pedoman dalam melaksanakan kegiatan-kegiatannya, sehingga dapat menetapkan program CSR yang bersinergi dengan nilai-nilai perusahaan menjadi hal yang penting.

Tim Public Relations PT Nutrifood Indonesia menerapkan konsep, yaitu program CSR harus sejalan dengan visi dan misi perusahaan, memberikan manfaat bagi masyarakat, dan berkolaborasi dengan pihak-pihak yang sejalan. Selain itu, terdapat pedoman dalam menjalankan program Health Agent Award 2015, yaitu Memorandum of Understanding antara PT Nutrifood Indonesia dengan Kementerian Kesehatan RI yang berjudul mendukung peningkatan sadar gizi masyarakat dalam percepatan pencapaian tujuan Sustainable Development Goals di bidang kesehatan.
Pada tahap ini, tim Public Relations menentukan target sasaran program Health Agent Award 2015 adalah komunitas sekolah dasar yang mayoritas siswanya berasal dari kalangan menegah ke bawah, pemahamannya tentang kesehatan masih kurang, dan fasilitas kebersihan, kesehatan, serta kantinnya masih memenuhi standar kelayakan. Kemudian, menentukan tujuan program Health Agent Award 2015, baik bagi perusahaan, komunitas sekolah dasar yang menjadi target sasaran, dan juga mahasiswa sebagai pihak ketiga.

Tim Public Relations juga sudah menentukan hasil yang ingin dicapai dalam program Health Agent Award 2015, yaitu para komunitas sekolah dasar dan mahasiswa memahami tentang asupan nutrisi, aktivitas fisik, dan higenitas pangan. Motif untuk mencapai target tertentu dapat dilihat dari upaya untuk menentukan tujuan (Lestari, 2014).

Pada tahap ini, tim Public Relations mencari partner kolaborasi yang merupakan para pemangku kepentingan (stakeholders) PT Nutrifood Indonesia untuk bersama-sama menjalankan program Health Agent Award 2015. Selain itu, tim Public Relations juga melakukan publikasi program Health Agent Award 2015 melalui media sosial dan media massa.

Fase pelaksanaan (do) dibagi Hohnen menjadi dua tahap, yaitu mengembangkan komitmen CSR (develop CSR commitments) dan implementasi komitmen CSR (implement CSR commitments). Komitmen CSR adalah kebijakan atau instrumen perusahaan dalam menunjukkan apa yang perusahaan ingin lakukan dalam mengatasi dampak sosial dan lingkungan. Komitmen CSR mengalir dari penilaian dan strategi CSR dan dikembangkan pada titik ketika sebuah perencanaan diimplementasikan dengan sebuah tindakan (Hohnen, 2007: 42).

Pada tahap ini, tim Public Relations memilih 15 tim mahasiswa untuk mengimplementasikan proyek kesehatan mereka dengan menjadi Health Agent di 15 sekolah dasar yang sudah ditentukan oleh PT Nutrifood Indonesia. Selain itu, tim Public Relations menjalin bekerjasama dengan Kementerian Kesehatan RI, Badan 


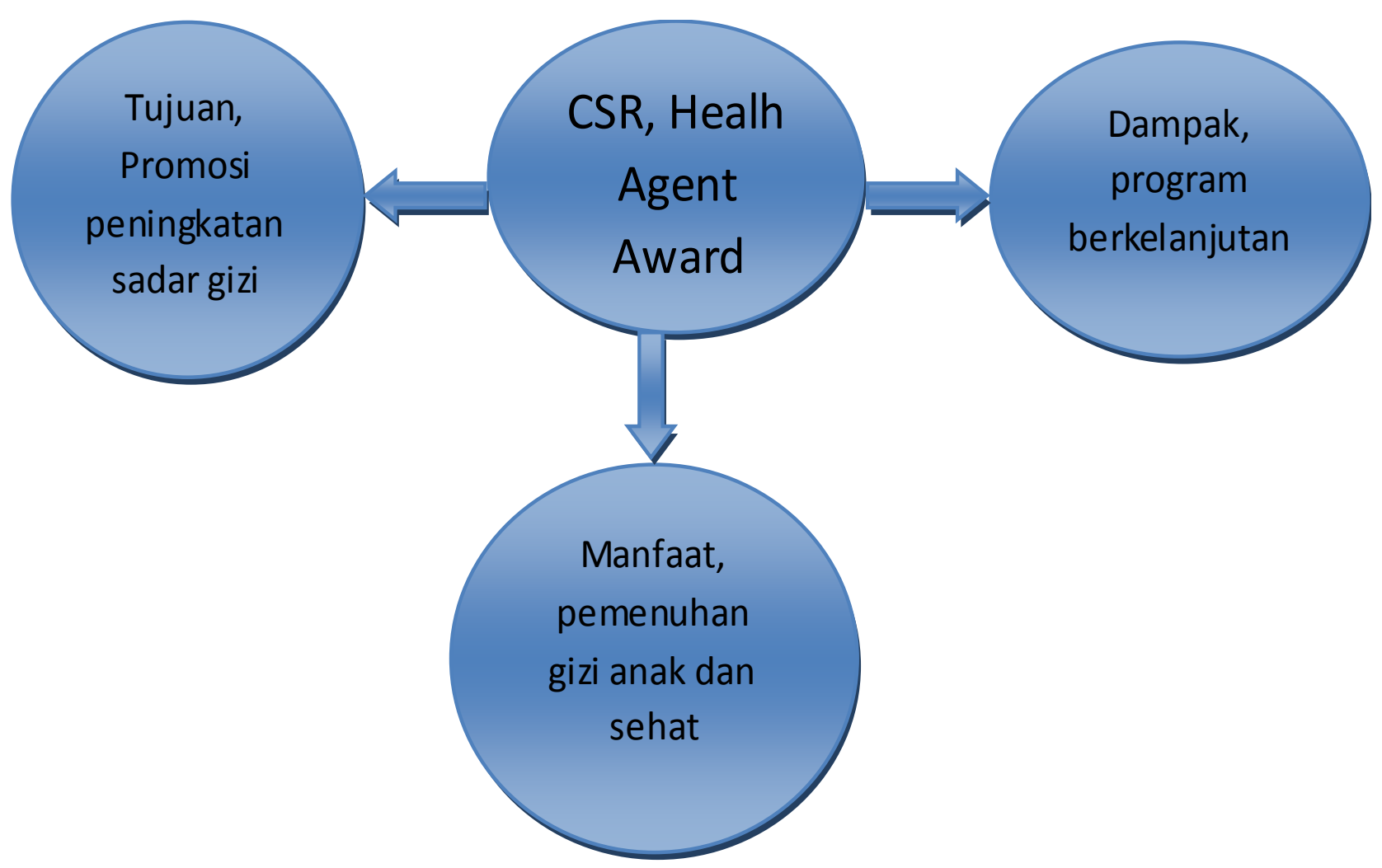

Sumber: Hohnen, 2007

\section{Gambar 1 Model CSR Program Health Agent Award PT Nutrifood Indonesia}

Pengawas Obat dan Makanan, dan Indonesia Mengajar dalam memberikan edukasi kepada para tim Health Agent sebelum turun ke lapangan.

Salah satu poin dalam mengembangkan komitmen CSR adalah melakukan diskusi denganpara stakeholders utama (Hohnen, 2007: 45), tim Public Relations PT Nutrifood Indonesia bersentuhan langsung dan berdiskusi dengan para stakeholders utama dalam program, yaitu mahasiswa dan pihak sekolah dasar. Diskusi dengan mahasiswa dilakukan saat PT Nutrifood Indonesia mengadakan briefing dan edukasi kepada para finalis Health Agent. Sedangkan, diskusi dengan pihak sekolah dasar dilakukan saat survey sekolah.

Implementasi mengacu pada keputusan sehari-hari, proses, praktik, dan kegiatan. Implementasi komitmen CSR dilakukan oleh tim Health Agent di sekolah dasar. Salah satu tim Health Agent dalam program Health Agent Award 2015 adalah tim Taruma Sakti. Tim Taruma Sakti mengimplementasikan proyek kesehatan yang diberi nama Program 3x3 = Sehat di SDN Tanah Sereal 01 Pagi. Implementasi dilakukan dengan cara: (1) Sosialisasi program kepada guru dan para murid; (2) Pembagian kuisoner kepada para murid untuk dijadikan indikator awal; (3) Eksekusi kegiatan-kegiatan proyek kesehatan yang meliputi tiga aspek, yakni asupan nutrisi, aktivitas fisik, dan higenitas pangan; (3) Eksekusi kick-off program; dan (4) Pembagian kuisoner kepada para murid untuk mengetahui hasil yang telah dicapai, serta meminta testimoni tentang program kepada para guru dan orang tua murid.

Salah satu poin dalam melaksanakan komitmen CSR adalah membuat perencanaan komunikasi intena dan eksternal (Hohnen, 2007: 57). Informasi mengenai komitmen CSR, program CSR, dan pelaporan kinerja harus dikomunikasikan kepada pihak-pihak yang terlibat, baik pihak internal perusahaan maupun pihak eksternal perusahaan, agar mereka mengetahui dan memandang CSR merupakan salah satu prioritas perusahaan. Pengkomunikasian dapat dilakukan melalui meeting dan pelaporan. Untuk pelaporan 
program, dilakukan tim Public Relations PT Nutrifood Indonesia melalui laporan divisi Corporate Communication, serta publikasi melalui official blog PT Nutrifood Indonesia dan juga berbagai media massa. Hal tersebut juga selaras dengan poin terakhir, yakni membuat komitmen dengan publik. Sebuah rencana eksternal yang baik harus mengidentifikasi individu atau kelompok yang perlu mengetahui adanya pelaksanaan CSR.

Sebagai sebuah program, CSR membutuhkan pengecekan untuk mengetahui hal-hal yang terjadi di lapangan selama program berlangsung, serta untuk menilai pencapaian kinerja yang telah dilakukan. Fase pengecekan terdiri dari pelaporan dan verifikasi kemajuan (report and verify progress). CSR pada akhirnya membahas peningkatkan kinerja, dengan demikian, pelaporan, verifikasi, dan jaminan adalah alat penting untuk mengukur apakah perubahan telah benar-benar terjadi, dan memperlihatkan kepada stakeholders seberapa baik perusahaan memenuhi komitmen dan efek apa yang terjadi.

Program Health Agent Award 2015 berupa kompetisi, maka pengecekan yang dilakukan PT Nutrifood Indonesia adalah dalam bentuk penjurian. Pengecekan hanya dilakukan sekali, yakni saat tim Health Agent melakukan kickoff program di sekitar minggu kedua sampai minggu keempat. Pengecekan dilakukan oleh tim Public Relations yang dibantu oleh tim Nutrifood Research Center (NRC) dan juga Badan Pengawas Obat dan Makanan (BPOM).

Indikator yang menjadi perhatian tim Public Relations saat melakukan pengecekan adalah: (1) Keberlangsungan program di lapangan oleh tim Health Agent, apakah sesuai dengan yang diajukan saat presentasi proposal; (2) Konten edukasi yang dibagikan oleh tim Health Agent kepada komunitas sekolah dasar, apakah sudah benar; dan (3) Kolaborasi yang terjadi antara tim Health Agent dengan pihak sekolah dalam menjalankan program.

Evaluasi bertujuan untuk melacak kemajuan dari keseluruhan pendekatan CSR perusahaan dan menjadikan acuan untuk perbaikan dan modifikasi di masa mendatang. Evaluasi memungkinkan perusahaan untuk melihat apakah CSR berada dijalurnya, dan apa yang perlu dilakukan agar lebih efektif.

Evaluasi program Health Agent Award 2015 dilakukan, baik oleh tim Health Agent maupun oleh tim Public Relations PT Nutrifood Indonesia. Evaluasi yang dilakukan oleh tim Health Agent terbagi menjadi dua, yaitu: (1) Evaluasi internal tim, dilakukan dengan cara mengobrol santai antar anggota tim; dan (2) Evaluasi eksternal, dilakukan dengan cara membagikan kuisoner kepada para murid dan pedagang kantin saat sebelum dan sesudah mengimplementasikan program. Hasil evaluasi eksternal disampaikan kepada tim Public Relations PT Nutrifood Indonesia dalam bentuk laporan dan presentasi.

Sedangkan, evaluasi oleh timPublic Relations PT Nutrifood Indonesia dilakukan dengan cara membagikan satu formulir evaluasi kepada setiap tim Health Agent saat selesai kegiatan edukasi, awarding session, dan juga setelah program Health Agent Award 2015 benar-benar berakhir. Hasil evaluasi disampaikan tim Public Relations kepada pihak top management, stakeholders, dan masyarakat luas. Evaluasi menjadi syarat yang harus dilakukan karena kegiatan evaluasi merupakan hal yang penting dalam mengukur keberhasilan program (Mayrizka, 2015).

Berdasarkan hasil evaluasi tim Public Relations mengetahui bahwa konten edukasi yang diberikan kepada para Health Agent sebelum turun ke lapangan, serta lokasi sekolah dasar yang dijadikan target sasaran perlu diperbaiki pada pelaksanaan program Health Agent Award selanjutnya. Sedangkan, konsep program, yaitu menggabungkan ide kreatif mahasiswa untuk diimplementasikan di sekolah dasar, dapat dilanjutkan untuk pelaksanaan program Health Agent Award tahun selanjutnya.

\section{SIMPULAN}

Berdasarkan dari hasil penelitian dan pembahasan yang sudah diuraikan, maka simpulan yang dapat diambil dari penelitian "Implementasi Program Health Agent Award 2015 Sebagai Bentuk Corporate Social Responsibility PT Nutrifood Indonesia” adalah 
sebagai berikut, pada tahap perencanaan program Health Agent Award 2015 sudah dilakukan oleh tim Public Relations PT Nutrifood Indonesia dengan baik dan sesuai dengan konsep yang ada, yaitu dengan menyelaraskan berbagai aspek dalam perusahaan, seperti visi, misi, tujuan, dan target sasaran. Akan tetapi masih ada satu kekurangan, yaitu top management tidak ikut terlibat.

Pada Tahap pelaksanaan program Health Agent Award 2015 yang dilakukan oleh tim Public Relations PT Nutrifood Indonesia maupun tim Health Agent sudah berjalan lancar dengan mengembangkan komitmen CSR dalam mengatasi masalah sosial dalam bidang kesehatan. Akan tetapi, pada saat pengimplementasian proyek kesehatan benarbenar diserahkan kepada tim Health Agent, tim Public Relations PT Nutrifood Indonesia tidak berperan aktif.

Tahap pengecekan program Health Agent Award 2015 sudah dilakukan dengan baik oleh tim Public Relations PT Nutrifood Indonesia dalam bentuk penjurian pada saat kick-off program di masing-masing sekolah dasar oleh tim Health Agent. Akan tetapi, pengecekan hanya dilakukan satu kali.

Tahap evaluasi program Health Agent Award 2015 sudah dilakukan dengan baik oleh tim Public Relations PT Nutrifood Indonesia dengan membagikan satu formulir evaluasi kepada setiap tim Health Agent, serta meminta testimoni dari perwakilan guru dan orang tua di setiap sekolah dasar. Akan tetapi, setelah program berakhir, tidak ada campur tangan lagi dari PT Nutrifood Indonesia untuk menjaga kestabilan program di sekolah dasar.

Pada tahap perencanaan program, sebaiknya tim Public Relations turut melibatkan pihak top management PT Nutrifood Indonesia dan lebih berperan aktif serta ikut terlibat saat tim Health Agent mengimplementasikan program di sekolah dasar dengan menjadi mentor di lapangan, tidak diserahkan penuh kepada tim Health Agent.

Pada tahap pengecekan program, sebaiknya tim Public Relations PT Nutrifood Indonesia melakukan pengecekan tidak hanya satu kali, melainkan paling tidak dua minggu sekali untuk mengetahui dan melihat perubahan-perubahan yang terjadi di lapangan.

Pada tahap evaluasi, tim Public Relations PT Nutrifood Indonesia sebaiknya memikirkan kembali cara untuk menjaga kestabilan program di Sekolah Dasar setelah program berakhir.

Penelitian ini dapat dilanjutnya oleh peneliti lainnya dengan melakukan penelitian mengenai efektivitas program Health Agent Award 2015 ini.

\section{DAFTAR PUSTAKA}

Arninta P. (2016, 3 Maret). PR manager pt nutrifood indonesia. Personal Interview

Faisal, S. (2007). Format-format penelitian sosial. Jakarta: Rajagrafindo Persada

Hohnen, P. (2007). Corporate Social Responsibility an implementation guide for business. Manitoba: International Institute for Sustainable Development

Lestari, E. (2014). Hubungan orientasi masa depan dengan daya juang pada siswasiswi kelas xii di sma negeri 13 samarinda utara. eJournal Psikologi Universitas Mulawarman, 2(3), 314-326

Mayrizka, D. (2015). Strukturasi implementasi kebijakan disabilitas. Jurnal Mahasiswa Sosiologi, 1(4), 1-33

Pratama, F. B. (2016, 7 Maret). ketua tim the hobbit. Personal Interview

Rakhmat, J. (2009). Metode penelitian komunikasi. Bandung: Remaja Rosdakarya

Rakhmawati,R.,\&Sani,A.(2016).Implementasi kegiatan corporate communication oleh divisi corporate secretary pt. bio farma (persero). Jurnal Profesi Humas, 1 (1), 40-52

Sugiyono. (2009). Metode penelitian kunatitatif, kualitatif, dan $r \& d$. Bandung Alfabeta

Yanto, A., Rodiah, S., \& Lusiana, E. (2016). Model aktivitas gerakan literasi berbasis komunitas di sudut baca Soreang. Jurnal Kajian Informasi \& Perpustakaan, 2 (1), $107-118$ 